\title{
On Study of New Approaches and Psychological Basis to Identify Pseudo Religions
}

\author{
XU Bibo, XIE Han, YAN Fumei \\ Hubei University, Hubei Province, China
}

\begin{abstract}
The study shows that pseudo religions are characterized by rapid spread and development, so it is a new approach to identify pseudo religions through this feature. The psychological mystery hidden in this characteristic is to turn believers into "mad missionaries", and this change is a result that believers are forced to preach pseudo religions by virtue of their fear to supernatural "Gods", their worship to "leaders of religions", their need going to heaven and by virtue of "Archimedes Effect" believed; leaders smartly force believers to preach religions through stimulation and incentives, and encourage believers to preach religions by virtue of endogenous incentives. This new approach and exposure of psychological basis relying on approach are significantly important to prevent formation and expansion of pseudo religions as well as even elimination.
\end{abstract}

Keywords: leader worship, mad missionary, archimedes effect, endogenous incentives

\section{Rapid Identification of Pseudo Religions Through Symbolic Features}

After the publicity and education on keeping away from pseudo religions for over decades in mainland China, most people know that pseudo religion is a malignant tumor all over the world, and object it. In recent years, in order to effectively prevent harm of pseudo religions on society, people, especially the young, and theoretical circles also conduct a profound research and exposure to pseudo religions through their characteristics so as to tell people how to identify pseudo religions through these characteristics, and keep way from them; meanwhile, they also list characteristics of pseudo religions at home and abroad different from those of orthodox religions: the "evil" in pseudo religions is that the living is viewed as secular worship leader of God. It controls believers mentally through brainwashing, hates reality and human development, harms believers, promotes witchcraft and superstitious culture and amasses wealth violently; if the public is told these features, they will identify pseudo religions rather than deceit, and they will identify them with orthodox religions, say no to and keep away from them, reaching the result of preventing spread of pseudo religions.

However, just as the saying that while the priest climbs a post, the devil climbs ten, pseudo religions good at disguising and deceiving always avoid exposure subtly and deceive believers to spread evils in the name of orthodox religions with changes. They are accustomed to stealing concept terminology, banners and titles of orthodox religions, and their members walk in the country holding scriptures and humorlessly talk about the Buddha speaks and Jesus Christ for the purpose of confusing audience, misleading believers and developing

XU Bibo, Associate Professor, Department of Psychology, Hubei University. XIE Han, Master Degree Candidate, Department of Psychology, Hubei University. YAN Fumei, Professor, Department of Psychology, Hubei University. 
believers through distorting dogmata and laws in orthodox religions. For example, Liu Jiaguo, leader of "Henotheism" asks his key believers to say they believe Christianity rather than the Lord. What pseudo religions do both humiliates orthodox and make it confused for believers who will take the wrong turning. The survey data show that most believers fall into the trap of pseudo religions under this deceit and believe them after capture. It is disturbing that we find in the process of exchanging with pseudo religions by mistake for a long time, once these people fall into a trap of orthodox, they would be convinced that what they believe is genuine orthodox religion, and here is an example about village believers of "Mentuhui". They firm believe what they believe is Jesus Christ, the Jesus, Christianity, and it is unbelievably difficult to change their ideas on pseudo religions and help them realize what they believe is pseudo religions. The author repeatedly tell believers of "Mentuhui" that what they believe is pseudo religion rather than orthodox Christianity in Sichuan and Hubei, however no matter what they say, believers turn a deaf ear. This makes authors feel that although we have collected different natures of pseudo religions and orthodox religions in order to help public identify pseudo religions, it is far from operable for the public who realize harm and refuse to join in pseudo religions subjectively, and especially the young to fast identify orthodox and pseudo religions by virtue of differential characteristics, therefore, authors need also explore and find some intuitive and operable identification methods to help people avoid pseudo religions, identify them when there is publicity, confusion and attraction, and keep away from them, effectively preventing the spread of pseudo religions in a broad social level.

After the observation and comparison for over a decade, we find an approach which can help the public rapidly identify what they encounter and experience is orthodox religion or pseudo religion: the public can be told to observe whether the one who preach religions to us is a crazy propagator or mad at religions he/she believes. Profoundly, it means you need to judge whether this propagator is addicted to "missionary" or becomes a "mad missionary", if so, he (she) must be a pseudo religion believer or organizations he/she encourages you to join in are pseudo religions. Because pseudo religion believers are mad propagators and it seems they are infected with "missionary", or become "mad propagators"; there is no such thing in orthodox religious. This is an effective way to help public identify pseudo religions cults through significant difference between pseudo religions and orthodox religions in spreading. This difference is not only reflected in the overall development momentum of both, but also in their believers, therefore people can identify believers' religions through their missionary behaviors.

The reason that pseudo religion believers are mad propagators and different from believers in traditional religions is that the latter boasts of a broad social foundation and many believers after thousands of years of development, and what it spreads is love and kindness which is able to meet people's belief, so many believers are attracted by them naturally; their existence, as for religious believers plays a role that a man of true worth attracts admiration. Pseudo religions spreading at home and abroad refer fanatical worship groups that emerged after the Second World War; they need to develop their organizations quickly, expand sites and cover a large believers and solid social foundation out of hatred to real world, covetous regime and wanton money collection as well as other political and economical purposes. Therefore, they ask their believers to preach religions desperately, and, considering loyalty and efforts of believers, they force them be infected with "missionary", and turn him/her into a "mad propagator". Many harm facts show that this purpose of pseudo religion and leaders has been reached. 


\section{Psychological Routes Turning Believers Into “Mad Propagators” by Pseudo Religions}

So what measures do pseudo religions and leaders take to make believers so crazy and to make them preach religions sparing no effort? Psychologically, five ways below are adopted by leaders of pseudo religions to stimulate and mobilize believers' missionary:

\section{Encouraging Believers to Preach Pseudo Religions Automatically by Supernatural “God”}

No matter あさはらしょうこう, the leader of Japanese Aum Doomsday Cult or Ji Sanbao in "Mentuhui", what they do firstly is to shape an image of endless power among believers through boasting, cheating, threatening, or implication in order to make believers preach religions for them insanely; Believers will fear the supernatural power of "God" and always fully do what they are told like a robot driven by others. Because pseudo religion believers are completely monotheists, they believe there is something above you! For example, what Liu Jiaguo, the head of "Henotheism" does is boasting that: "we have to believe God Father in heaven, master underground and I am that Master," when women do not want to be a "believer", he threats them by the so-called "Elders", "Lord First" and leaders of cult organizations: "If you do not, you will suffer disasters; as Lord know everything, you life lies in his hands" (Jiang, 2001).

The reason why pseudo religion believers fear God and become "mad propagators" is that their fear to supernatural power is different with that to laws. Afraid of law, people dare not to do things illegally in front of the law, but they will do so when there are no laws or under the domination of fluke mind; many social illegal cases have proved this; their fear to God means they will not do anything against God in any place, and even ideas against Gods in mind, so when leaders - the supernatural God for believers asks him (her) to preach religions, to save the world and to enhance themselves mentally and ethically, it is impossible for them to make some delay.

\section{Encouraging Believers to Preach Pseudo Religions Automatically by "Leader Worship”}

When leaders of pseudo religions apply extremely mean ways above to shape their "God" images among believers, they also establish their "leader worship" among believers psychologically, and it is such worship that makes pseudo religion believers the mad propagators and drive them to conduct fanatical missionary.

Psychologically, it is believed that "leader worship" is an extreme personal worship, a kind of worship among many human worship behaviors, and in fact, is the individual influence alienation of leaders in a group. Once leaders establish their absolute worship among believers psychologically, believers will be deprived of independent sense of autonomy and thinking ability out of worship, and then will regard apostasy of leader as truth.

The Cognitive Psychology holds that "affection comes from intelligence" or "affection comes from thinking" in terms of relationships between sense and sensibility. It emphasizes that affection comes and varies from his thought and his ideas on things, which is in line with the saying "the more you know, the much you will love"; this means they agree that knowing process is the premise and foundation to produce affection, so believers will produce complex emotions to leaders like respect, awe, obedience, reverence, esteem, appreciation, admiration, trust and intimacy when they receive rational fallacies of leaders, honor leaders as "Masters" controlling universe, earth and space, and "King of kings", and when worship leaders (Zhu, 2002).

The study of psychology shows that as for a psychologically normal person, his behaviors are controlled rationally and dominated emotionally: a rational understanding refers a compass and steering wheel of one's behaviors, while emotion is his motive and power, so if one takes actions by virtue of sense, these actions shall 
be mechanical, pale, and weak; otherwise, if one takes actions by virtue of impulses, these will be blind and hard for enduring.

The establishment of leader worship refers pseudo religion believers fully receive fallacies of leaders rationally, but their understanding and actions are controlled by sense and although the sense refers a wrong sense guided by false reasoning of leaders; meanwhile, according to the principle above that "affection comes from intelligence" or "affection comes from thinking" in cognitive psychology, they tend to love, awe, admire, obey, depend on and intimate leaders inevitably and, of course, their actions are supported by emotions. This means that as for psychology and actions of pseudo religions believers based on leader worship, its driving force behind is a strong motive force dominated by sense and sensibility, and their behaviors are incomparable for those dominated by sense or single force.

Therefore, once leaders establish "leader worship" among believers psychologically, they are able to control believers psychologically and behaviorally by virtue of dual motive forces, sense and sensibility caused by worship, which will allow believers to donate property and even body and life to evil leaders. So when leaders of pseudo religions ask them to spread evil dogmata and save the living, to regard "missionary work" as "great service to mankind" and "prehistoric aspiration" and require each believer to spread missionary work by using all favorable conditions...and each should take "carrying out missionary work" as his duty, is there a faithful cult believer who do not preach religions as mad and who ropes in people he knows, especially those who are highly educated, respectable, have advanced social status and influence to believe pseudo religions? It is easy to understand why pseudo religion believers tend to preach religions initiatively, fanatically and industriously when one understands this point.

\section{Encouraging Believers to Preach Religions by Their Need Going to Paradise}

According to leaders of pseudo religions, believers believe the more people they reform, the much merit they accumulate, increasing their white matter which will help them get fruits, success and a higher level. In other words, the more people they reform, the closer they are to "paradise", "Falun world" and "heaven" constructed by leaders of pseudo religions. The study of psychological state of cult believers shows that he (she) is afraid death subconsciously, wanting to live forever and going to paradise are innermost ideas of believers or are the strong sources and most intense wishes hidden in his (her) subconscious. Feuerbach (1984), a German philosopher says: "there is no such thing like death if people can live forever, so, there will be no religion." Xiong Bolong (1979), an atheist in Qing Dynasty in Hubei also says: "the reason people fear Gods is the death...Their fear to death comes first followed by that to God." Although we do not approve pseudo religions which can be compared with traditional religions, as for believers, they are pure religions.

In view of the ultimate emotion of people who fear death and desire eternality, religions try to tell people that death and fear to death can be overcome by believing religions, so it is a natural reason for production and existence of religions and even pseudo religions to avoid death and obtain eternality. Imagine that are there believers of pseudo religions who believe religions without purposes of escaping death, seeking eternal life, and going to heaven early? Although no one among them has been fully aware of this, this need and desire are strong in their subconscious. Pseudo religions and leaders, taking advantage of this psychological need of believers, repeatedly claim that only it can meet this need and can encourage believers like fully-wound robots to preach pseudo religions and bring more people in. 


\section{Encouraging Missionary of Believers by “Archimedes Effect”}

"Archimedes Effect" refers a passionate narration state when that Archimedes, the ancient Greek scientist is so ecstatic after discovering Archimedes law (Archimedes law) in physics that he wants to immediately tell it to all. Not long ago, he asks a craftsman to create a golden crown for him and the king gives the craftsman the needed amount of gold. The craftsman is so clever that crown made is chic and it is as same as gold given. However someone tells the king: "craftsman engulfs some gold in production and silver with same eight is mad into." After listening this, the king suspects and asks Archimedes to measure whether silver is made and craftsman engulfs the gold. This confuses Archimedes who thinks about it for a long time, however there are no solutions; he has no mood at eating, sleeping, and bathing as if crazy.

One day, the king asks him to report to palace. His wife sees him too dirty and forces him to take a bath. He still thinks of the problem when taking a bath. Suddenly, he notices that when his body sinks in the tub, some water overflows. Meanwhile, he feels the deeper the body goes into, the lighter the amount of his body. So he immediately jumps out of the tub and runs to streets naked. He cries while running, "I think it out, I find solution to weight crown!"At this moment, he is so excited for this finding that he would like to tell this to the whole world, so this passionate narration or emotion is called Archimedes effect.

The Archimedes effect will occur when believers of pseudo religions are completely captured by pseudo religions and deeply obsessed with them, when believe the remark that immortality cultivation can save souls and that they can go to heaven after a successful cultivation where trees, soil, birds, flowers, houses and even Buddha are gold, and where you can get anything you want. They will be as excited as Archimedes who finds buoyancy principles psychologically or emotionally and produces passionate emotion so that fails to control themselves and claim: "I find $\times \times \times$ religion which can save souls to help us go to heaven!" "I find ways for soul immorality and to go to heaven!" Believers will repeatedly say how wonderful their pseudo religions are and magic; they will encourage innocent people to be believers tirelessly and their exciting shall not be vented if they don't do in such a way, which will also makes them bored, restless, and even suffocated.

It is easy to understand why believers of pseudo religions preach their religions as long as there are chances and are excited when preaching and encouraging people after understanding this, which also can be said that this is one reason that pseudo religions turn believers into "mad propagators".

\section{Encouraging Believers to Preach Religions With Incentives}

William James, known as the father of American psychology argues that display of people's ability and enthusiasm rests with $80 \%-90 \%$ of excitement. This means that a person will do something after of encouragement. It shows that it is incentive that encourages believers to desperately preach religions, and so what incentives do they get to preach religions fanatically?

The psychology divides incentives materially and spiritually. The former refers money, cars, and villas given to people who make a great job, and the latter refers honor and title granted; so whether material or spiritual incentives do the fanatical missionary get from leaders of pseudo religions? It is material incentive. Although leaders fail to award fanatical missionary with money, cars, and villas, a pursuing goal and promising promise are given: good cultivation brings you to paradise. Because one can get whatever he wants, this goal and promise are material. However this is a promise which cannot be true when believers are alive, a goal which cannot be checked whether it is reached and a false goal; "there is no failure at all when one decides to contribute his life to a false target never practical (Pepe, 2001). Those who are inspired by this incentive always 
experience self-success and feel that the more people they bring into religions, the closer they are to target - paradise. It is this experience that inspires cult believers to teach evil spirits, to persuade and win over every person relentlessly and culturally he encounters to believe in cults and join in cult groups.

Goals and promises given by pseudo religions given to believers are sham, but they are in line with laws of psychology in terms of enthusiasm mobilized to spread pseudo religions. The needs theory in psychology holds that the unmet need is the starting point of incentive process and incentive is useful when catering to unmet needs, and once the need is met, goals reached, it is end for incentive (Stephen, 1997). Promises and goals offered to believers by pseudo religions and leaders are goals which are false and will never be true, so they can drive believers to spread cults and expand cult organizations never-ending in virtue of promises and goals.

\section{Encouraging Believers to Preach Religions Spontaneously by Endogenous Incentives}

Leaders of pseudo religions are good at using unpractical promises and goals to stimulate believers to preach religions desperately, but also understand superior endogenous incentives a profound potential which are regarded as codes inspiring believers to conduct missionary and to mobilize believers' enthusiasm for spreading.

The psychology divides people's behavioral motives into endogenous motivations and exogenous motives in study (Fred, 2003). Behavior motives stimulated by material rewards or spiritual rewards offered externally are exogenous motives while endogenous motives refer behavior motives produced by people' interest in engagement and activities. If people are interested in jobs and activities, and what stimulates people endogenous motives is not material reward or spiritual reward provided externally, but the occupations and activities engaged; jobs and activities are challenging and creative as well as of great significance, so they will be satisfied with occupations and activities and work with motives. Moreover, such consequences of occupations and activities make them psychologically experience sense, honor, pride and happiness which allow workers and actors to get satisfaction which actually is a self-reward or remuneration for them. With such self-reward or remuneration, workers and actors will never be bored with such job and activities even in the absence of any external incentives. This is like a person who conducts creation nothing to do with his own business, and even leaders do not give him any material and spiritual support and say he is a trifler, he will still be engaged in it as long as he is interested in such creation. Results achieved, he will experience emotions like sense of accomplishment, honor and pride which satisfy him and encourages him to carry out profound innovation.

Psychology refers endogenous incentives to people's interest in work and activities, changes in work and activities, creativity, lofty meaning and sense of honor and pride produced work and activities, and activity motives inspired by endogenous incentives are endogenous motivations. Unlike those who are externally motivated or "forced to do it", actors inspired by endogenous incentive are "willing to do it", so it obvious that people who are "willing to do" will be more enthusiastic to occupations than those who are "forced to do".

It seems that leaders of pseudo religions understand inner incentive, so believers are never rewarded with money, and are willing to preach pseudo religions selflessly and desperately under encouragement of endogenous incentives. They adopt two ways for incentives: the first one refers a promise which assures believers the more people they bring in, the earlier they will become God or celestial being, which is an earnest dream playing an incentive role for believers; another one refers improving believers' status to make them feel superior morality, self-elitism, and pride. Such as Applewhite, leader of "Gates of Paradise" in America claims 
he comes to save lives in external space where his followers come, and he raises status of believers, making them experience superiority, self-elitism, and pride under endogenous incentives.

\section{References}

Chen, Z., \& Zhang, X. L. (2001). The truth of pseudo religion. Beijing: Contemporary World Press.

Feuerbach, L. (1984). Selected works of Feuerbach's philosophy (Vol. 2). The Commercial Press.

Fred, L. (2003). Organizational behavior. Beijing, Post \& Telecom Press.

Jiang, J. S. (2001). Tumor-On study of pseudo religions in China. Beijing: Mass Media.

Li, Z. (1999). Pseudo religion, secret societies, Gangsterdom. Beijing: Mass Media.

Lv, D. J. (1999). New general theory of religion. Beijing: Social Sciences Press.

Lv, H. R., \& Xin, S. J. (1988). Mystery religion. Zhengzhou: Henan People's Press.

Meadow, M. J. (1988). Religious psychology. Sichuan: Sichuan People's Press.

On study of pseudo religions. (2003). Nanning: Guangxi People's Press.

Pepe, R. (2001). Obsessed pseudo religions-Nature, prevention and disposal of pseudo religions (L. Shi, Trans.). Beijing: Xinhua Publishing House.

Stephen, P. R. (1997). Organizational behavior. Beijing: China Renmin University Press.

$\mathrm{Su}, \mathrm{H}$. (2006). Mystery of mystical belief. Nanjing: Jiangsu People's Publishing House.

Tian, M. (2011). Cults inside out. Wuhan: China Anti-cult Association.

Xiong, B. L. (1979). Wuheji. Zhonghua Book.

Угринович, Д. (1989). Religious psychology. Social Sciences Academic Press (CHINA).

Zhu, Y. X. (2002). Management psychology. Beijing: Higher Education Press. 